East African Medical Journal Vol. 80. No. 8 August 2003

PAIN MANAGEMENT IN MICE USING THE AQUEOUS AND ETHANOL EXTRACTS OF FOUR MEDICINAL PLANTS

A. Debella, PhD, Department of Drug Research, Ethiopian Health and Nutrition Research Institute, P.O Box 1242, Addis Ababa, Ethiopia, E. Makonnen, PhD, Department of Pharmacology, Faculty of Medicine, Addis Ababa University, P.O Box 9086, Addis Ababa, Ethiopia, D. Adebe, PhD, F. Teka, Dip Chem; and A.T. Kidanemariam, MSc, Department of Drug Research, Ethiopian Health and Nutrition Research Institute, P.O. Box 1242, Addis Ababa, Ethiopia

Request for reprints to: Dr. A. Debella, Department of Drug Research, Ethiopian Health and Nutrition Research Institute, P.O Box 1242, Addis Ababa, Ethiopia

\title{
PAIN MANAGEMENT IN MICE USING THE AQUEOUS AND ETHANOL EXTRACTS OF FOUR MEDICINAL PLANTS
}

\author{
A. DEBELLA, E. MAKONNEN, D. ABEBE, F. TEKA and A. T. KIDANEMARIAM
}

\begin{abstract}
Background: There are many traditionally used analgesic plants in Ethiopia. They, however, have not been subject to scientific investigation for their efficacy and safety.

Objective: To evaluate both prophylactic and relieving effects of aqueous and ethanol extracts of four traditionally used medicinal plants in Ethiopia.

Design: An experimental design in which five group of albino mice weighing 30-35 grams representing positive and negative control, and extract treated groups respectively. The extracts, standard drugs and normal saline were administered into GIT by gavage to evaluate the analgesic effect.

Setting: Department of Drug Research at Ethiopian Health and Nutrition Research Institute and Department of Pharmacology at Faculty of Medicine, Addis Ababa university.

Methods: Analgesic effects of water and ethanol extracts of four plants were evaluated against distilled water and standard analgesics (morphine and acetylsalicylic acid) with acetic acid induced writhing tests in mice. The four plants used for this screening were Ocimum sauve, Ocimum lamiifolium, Lippia adoensis and Ajuga remota.

Results: All extracts of the four plant materials were observed to possess both inhibiting and treatment activities against acetic acid induced pain. Dose related analgesic effect was also observed with all extracts of all plants with different potencies. Ethanol extracts of all the four plant materials were more potent than their water extracts at all dose levels except $O$. sauve, and $L$. adoensis whose water extracts seem to be a bit more potent at low dose. The analgesic potencies of both extracts of all the four plants were shown to be less than those of the standard analgesics. Of all the extracts, the ethanol extract of $O$. lamiifolium was found to be the most potent, while its water extract was the least. Acetic acid induced writhing was relieved with medium dose of both extracts in most cases and with low dose in few. Hundred percent relief was achieved with both standard analgesics at a very low dose.

Conclusion: The present study show that all the extracts of all the plant materials have got both inhibiting and relieving effects of pain.
\end{abstract}

\section{INTRODUCTION}

In the ethnomedical system of Ethiopia, quite a large number of plants are used to treat ailments associated with pain like headache, stomachache, common cold etc. Preparations derived from plants are commonly employed to treat illness of traditional classification like "Meggannya" symptoms associated with renal or hepatic colic, dizziness and vomiting and "Mitch" manifested by headache, chills and abdominal colic $(1,2)$.

Among the commonly used analgesic and antipyretic herbs, the leaves of "Ocimum sauve Willd(Labiatae)" local name "Dama-kessie" (Amharic) "Kefosa" (Oromifa), Ocimum lamaiifolium Hochst ex Benth (Labiatae) "local name "Anchabi" (Oromifa)", Ajuga remota Benth (Labiatae) "local name "Harma-gusa",
Gondie (Oromifa) " and Lippia adoensis (Verbenaceae) "local name Koseret, Kessie (Amharic), Kusaye (Oromifa)" are shrubs occurring in different regions of Ethiopia at an altitude between $1600-2200 \mathrm{~m}$. The mode of administration usually involves squeezing the fresh leaves and sniffing the juice, drink or inhale after boiling in water (2-4) .

Although there are some reports on antimycobacterial, cardiotonic and antihypertensive effect of Ajuga remota (5-7), and antibacterial and antifungal activities of the essential components of Ocimum species (8-10), no study was made regarding their possible analgesics effect. Therefore, in an attempt to validate the traditional claim, the present study was carried out to investigate the ethanol and aqueous extracts of the plant materials. 


\section{MATERIALS AND METHODS}

Animals: All experiments were performed on mice (albino males, in-house bred, weighing 30 to $35 \mathrm{~g}$ ). They were kept in cages in an animal house with a 12-h light-dark cycle. They were fed on pellets and tap water ad libitum. All the tests were carried out in a quiet laboratory setting with ambient illumination and temperature close to those of the animal house. Mice were allowed to acclimatize to the testing area for one hour before the experiments began.

Standard drugs: Acetyl salicylic acid was obtained from Evans Lot No. SJ22401 and morphine $\mathrm{HCl}$ was manufactured by SIGMA and obtained from Lion Pharmacy, Ethiopia.

Plant materials: Collection and identification. The leaves of Ocimum sauve, O. Iamiifolium and Lippia adoensis were collected from Bedabuna and Dengewajie, near Jimma and Bedele towns 324 and $393 \mathrm{~km}$ south west of Addis Ababa, and the leaves of Ajuga remota was collected near Gorro, a town 162 $\mathrm{km}$ South West of Addis Ababa in January, 2000 at an altitude between 1600-2200 m respectively.

All the specimens were identified by a taxonomist and a voucher sample representing Ocimum sauve (Herbarium No. 1142), O. lamiifolium (Herbarium No. 1141), Lippia adoensis (Herbarium No. 1140) and Ajuga remota (Herbarium No. 1145) were deposited at the Herbarium of Department of Drug Research, Ethiopian Health and Nutrition Research Institute, Addis Ababa, Ethiopia.

Preparation of extracts: Air dried and powdered leaves of Ocimum sauve (218 g), O. lamiifolium (120 g), Lippia adoensis $(220 \mathrm{~g})$ and Ajuga remota (232 $\mathrm{g}$ ) were extracted with petroleum ether $\left(40-60^{\circ} \mathrm{C}\right)$ and ethanol successively using soxhlet apparatus. These were concentrated in vacuo to give $9.6 \mathrm{~g}, 10.5 \mathrm{~g}, 8.6 \mathrm{~g}$ and $6.0 \mathrm{~g}$ gummy residues from ethanol concentrates, respectively.

Sixty gram of powdered leaves of the above plants were also separately macerated with cold water and lyophilized to give 7.6g, $5.3 \mathrm{~g}, 6 \mathrm{~g}$ and $5.5 \mathrm{~g}$ powdered residues, respectively. The extracts were kept in a tightly stoppered bottles and stored in a desicator. The gummy residue and lyophilized powder were reconstituted in distilled water to get the desired concentrations for the pharmacological tests.

Treatments: Extracts, standard drugs and distilled water were injected into the GIT by gavage. Three dose levels, namely low dose (400 mg/kg-body wt.), medium (600 mg/Kg-body wt.) and high ( $800 \mathrm{mg} / \mathrm{kg}$-body wt.), were selected from the pilot study carried out in mice based on the information obtained from traditional healers.

Test for Analgesia: Mice were pretreated by gavage with one of the extracts, standard drugs or distilled water, then placed in a clear perspex box and left for one hour. Then $0.35 \mathrm{ml}$ of $0.6 \%$ acetic acid solution was administered intraperitoneally to each mouse. Abdominal constrictions (writhes) consisting of contraction of muscles in conjunction with hind limb stretching were expected to be observed in unprotected mice as described by Koster et al. (11). Writhes were counted for 20 minutes and 10 minutes after acetic acid injection. Inhibition against acetic acid induced pain was expressed as reduction in the mean number of writhes for control mice verses extract or standard drug treated mice as described by Vazet al. (12).

To determine relief, acetic acid induced writhes were counted for 20 minutes and 10 minutes after administration of low dose of the respective extracts or $100 \mathrm{mg} / \mathrm{kg}$ acetylsalicylic acid or $10 \mathrm{mg} / \mathrm{kg}$ morphine. Relief against acetic acid induced pain was given as the number of mice relieved with the low dose, i.e., $400 \mathrm{mg} / \mathrm{kg}$ expressed in percentage of the total animals.

Statistical analysis: Data were expressed as mean \pm SEM. Statistically significant differences between treatment groups were evaluated by Dunnett's multiple comparison test.

\section{RESULTS}

Phytochemical screening of both ethanol and aqueous extracts has revealed the presence of phenolic compounds as a major chemical constituents in all plant materials employed for this study.

Both water and ethanol extracts of the four plant materials showed inhibition and relief against acetic acid induced writhing (Tables 1 and 2). Dose related analgesic effects were also observed with extracts of all the four plant materials with different potencies (Tables 1 and 2). Ethanol extracts of all plant materials employed in this study were found to be more potent than their water extracts at all dose levels except $O$. savve and $L$. adoensis whose water extracts seem to be a bit more potent at low dose, i.e., $400 \mathrm{mg} / \mathrm{kg}$ (Table 3 ). The analgesic potencies of both extracts of all the four plant materials were shown to be less than those of the standard analgesics (Tables 1, 2 and 3). The ethanol extract of $O$. lamiifolium was observed to be the most potent while its water extract was the least (Tables 1, 2 and 3). Acetic acid induced writhing was observed to be relieved with medium dose of the extracts in most cases and with low dose in few (Table 4). Hundred percent relief was achieved with both standard analgesics at a very low dose (Table 4).

Table 1

Protective effects of water extract of some medicinal plants against acetic acid induced writhing as compared to those of the standard analgesics

\begin{tabular}{|c|c|c|c|c|c|c|}
\hline \multirow[b]{2}{*}{ Name of plant/drug } & \multirow[b]{2}{*}{ Control } & \multicolumn{5}{|c|}{ Number of writhing } \\
\hline & & $20 \mathrm{mg} / \mathrm{kg}$ & $200 \mathrm{mg} / \mathrm{kg}$ & $400 \mathrm{mg} / \mathrm{kg}$ & $600 \mathrm{mg} / \mathrm{kg}$ & $800 \mathrm{mg} /$ \\
\hline O. Iamiifolium & $70.0 \pm 2.6$ & - & - & $54.9 \pm 4.1$ & $43.9 \pm 4.9$ & $40.5 \pm 6.5$ \\
\hline O. sauve & $57.6 \pm 6.0$ & - & - & $38.4 \pm 6.2$ & $37.6 \pm 6.5$ & $26.9 \pm 7.5$ \\
\hline L. adoenisis & $51.3 \pm 5.0$ & - & - & $27.5 \pm 9.0$ & $21.6 \pm 4.8$ & $17.5 \pm 9.5$ \\
\hline A. remota & $65.1 \pm 4.0$ & - & - & $38.5 \pm 8.9$ & $37.0 \pm 4.5$ & $30.8 \pm 9.1$ \\
\hline Acetylsalicylic acid & $73.1 \pm 2.5$ & - & $20.6 \pm 8.0$ & - & - & - \\
\hline Morphine & $59.3 \pm 4.0$ & $1.3 \pm 0.8$ & - & - & - & - \\
\hline
\end{tabular}

$\mathrm{n}=8-10, \mathrm{p}<0.01$ for all values, data are expressed as mean \pm SEM

The control values are responses to normal saline before use of the respective extract or standard. 
Table 2

Protective effects of ethanol extract of some medicinal plants against acetic acid induced writhing as compared to those of the standard analgesics

\begin{tabular}{|c|c|c|c|c|c|c|}
\hline \multirow[b]{2}{*}{ Name of plant/drug } & \multicolumn{6}{|c|}{ Number of writhing } \\
\hline & Control & $20 \mathrm{mg} / \mathrm{kg}$ & $200 \mathrm{mg} / \mathrm{kg}$ & $400 \mathrm{mg} / \mathrm{kg}$ & $600 \mathrm{mg} / \mathrm{kg}$ & $800 \mathrm{mg} / \mathrm{kg}$ \\
\hline O. Iamiifolium & $74.0 \pm 7.5$ & - & - & $30.9 \pm 7.0$ & $24.3 \pm 8.6$ & $1.1 \pm 0.9$ \\
\hline O. sauve & $60.8 \pm 5.2$ & - & - & $41.7 \pm 9.1$ & $35.7 \pm 3.9$ & $26.0 \pm 5.2$ \\
\hline L. adoensis & $59.4 \pm 6.9$ & - & - & $36.6 \pm 10.0$ & $21.2 \pm 5.8$ & $12.8 \pm 4.6$ \\
\hline A. remota & $65.8 \pm 3.9$ & - & - & $26.5 \pm 7.9$ & $17.3 \pm 9.0$ & $8.9 \pm 4.1$ \\
\hline Acetylsalicylic acid & $73.1 \pm 2.5$ & - & $20.6 \pm 8.0$ & - & - & - \\
\hline Morphine & $59.3 \pm 4.0$ & $1.3 \pm 0.8$ & - & - & - & - \\
\hline
\end{tabular}

$\mathrm{n}=8-10, \mathrm{p}<0.01$ for all values, data are expressed as mean \pm SEM

The control values are responses to normal saline before use of the respective extract or standard.

Table 3

Percent protection against acetic acid induced writhings

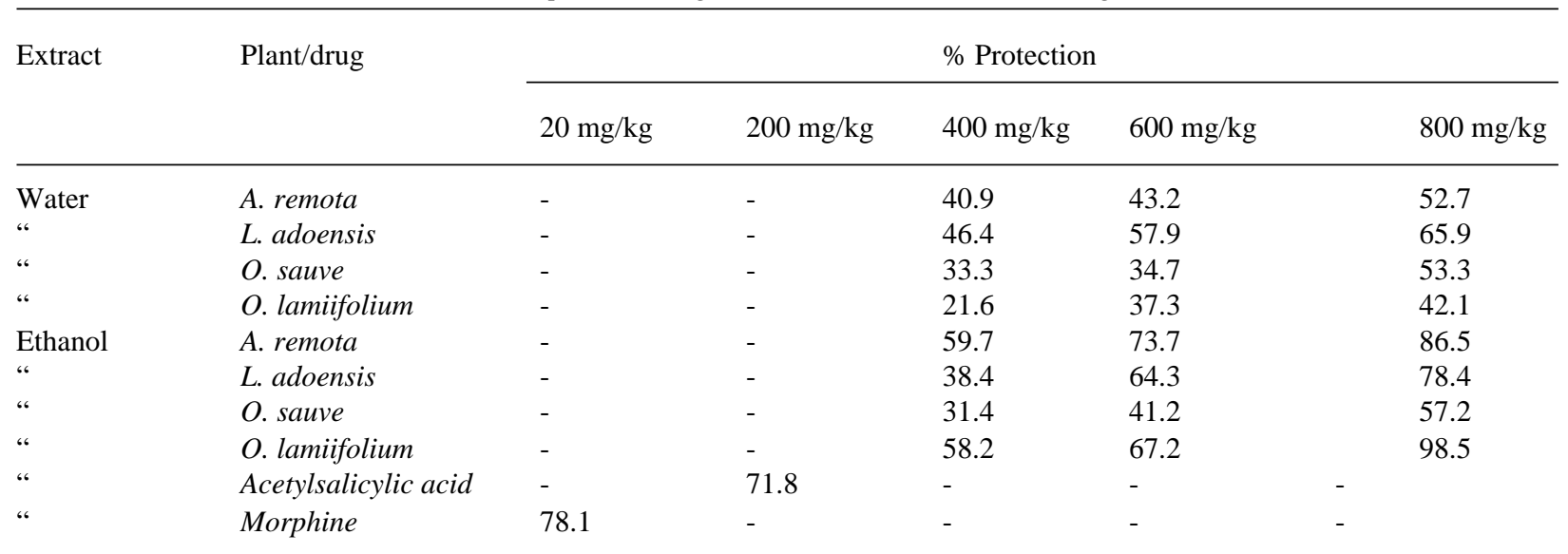

Table 4

Number of mice relieved with $400 \mathrm{mg} / \mathrm{kg}$ extracts, $100 \mathrm{mg} / \mathrm{kg}$ acetylsalicylic acid and $10 \mathrm{mg} / \mathrm{kg}$ morphine from acetic acid induced writhes

\begin{tabular}{|c|c|c|c|}
\hline Extract & Plant/Drug & Dose & No. of animals relieved $(\%)$ \\
\hline Water & A. remota & $400 \mathrm{mg} / \mathrm{kg}$ & 70 \\
\hline Ethanol & A. remota & “ & 40 \\
\hline Water & L. adoensis & “ & 0 \\
\hline Ethanol & L. adoensis & “ & 0 \\
\hline Water & O. lamiifolium & “ & 60 \\
\hline Ethanol & O. lamiifolium & “ & 80 \\
\hline Water & O. sauve & “ & 40 \\
\hline Ethanol & O. sauve & “ & 0 \\
\hline- & ASA & $100 \mathrm{mg} / \mathrm{kg}$ & 100 \\
\hline- & Morphine & $10 \mathrm{mg} / \mathrm{kg}$ & 100 \\
\hline
\end{tabular}

ASA = acetylsalicylic acid 
The mice that were used in this study were closely observed for about a month after administration of low, medium and height doses. In due course all the mice were survived and none of the mice showed any manifestation of toxicity. This showed that the doses administered to the mices were safe.

\section{DISCUSSION}

Pain represents the sum of reactions which include specialized and non-specialized tissues, as well as psychological and cognitive reactions to painful stimuli (13). A useful way of categorizing pain for purposes of studying analgesics is to distinguish between visceral and somatic types (14). Visceral pain is perceived as a diffuse and burning sensation, while somatic is localized and sharp.

Trentin et al. reported that a plant extract evaluated for analgesic properties significantly affected abdominal constrictions, i.e., writhes (15). That was why this was considered one of the tests to screen for analgesic properties of a new chemical entity.

It might be difficult to categorize acetic acid-induced abdominal constrictions to somatic or visceral pain though some investigators categorized it as a visceral pain. The observation that morphine and acetylsalicylic acid showed different potency against acetic acid induced writhing explains the difference in mechanism of action. Morphine by acting on opioid receptors relieves visceral pain, while acetylsalicylic acid by inhibiting prostaglandin synthesis relieves only somatic pain.. Ibuprofen, which acts by the same mechanism was observed to be more effective against acetic acid induced abdominal constrictions (16). From this, one may conclude that acetic acid induced pain represents somatic pain, which is not in agreement with the previous classification by Connor et al. (17). So it is difficult to come up with the precise mechanism of analgesic action of the plant extracts with the present test. More analgesic tests may, therefore, be needed to get more idea about their mechanisms of action.

The relieving dose was observed to be lower than the prophylactic one in all cases. This may be explained in terms of distribution of the extracts in the body. When the extract was given before pain induction, some might have already been distributed elsewhere in the body other than the site of action with time. The distribution, however, might be less when the extract was administered after pain.

The highest potency observed with ethanol extracts could explain that the active components are more soluble in ethanol than in water. The presence of phenolic compounds as a major chemical constituents in the extracts may demonstrate the contribution of these compounds for anlgesia observed in the present study. The investigated plants ethanol extracts showed comparable analegesic property as that of the ethanol extract of Taverniera abyssinica (Dagne et al.. 1990) though the present extracts seem to be less potent.
Further investigation should be pursued after isolation and identification of the active components in order to come up with the active components responsible for the analgesic properties of the plant materials.

Conclusion: The inhibitory and relieving effects of the investigated plant extracts supports their folklore use. Work is in progress to elucidate other pharmacological properties and toxicity profile of the extracts. Furthermore, isolation and characterization of the active principles and screening for analgesics properties are also underway.

\section{ACKNOWLEDGEMENTS}

The research was supported by the Ethiopian Health and Nutrition Research Institute and carried out in the Department of Pharmacology, Faculty of Medicine, Addis Ababa University. We appreciate the technical assistance of Agere Yigezu and the careful animal handling of Baysasahu G/Medhin of the Department of Pharmacology.

\section{REFERENCES}

1. Vecchiato, N.L. Traditional Medicine. In Kloos, H. and Zein, Z.H (ed), The Ecology of Health and Diseases in Ethiopia. West View Press Inc., San Francisco. 1993, 157-175.

2. Kloos, H., Tekele, A., Yohannes, L., Yosef, A. and Lemma, A. Preliminary studies of traditional medicinal plants in nineteen markets in Ethiopia: use patterns and public health aspects. Ethiop. Med. J. 1978; 16:33-44.

3. Abebe, D. and Ayehu, A., Addis. Medicinal plants and Engymatic Health practices of Northern Ethiopia, Berhanena Selam Printing Press. Ababa, 1993; 219.

4. Abate, G. Etse Debddabe, Addis Ababa University Press, Addis Ababa. 1989; 192.

5. Centrell, C.C., Rajab, M.S., Frazblau, S.G., Froncezk, F.R. and Fischer N.H. Antimycobacterial ergosterol- 5, 8endoperoxide from Ajuga remota. Planta Medica. 1999; 6: 732-734.

6. Dagne, E., Yenesew, A., Capasso, E., Mascalo, N. and Pinto, A. Preliminary studies on antipyretic analegsic properties of Taverniera Abyssinica. Ethiop. Med. J. 1990; 28:155-160.

7. Ogunde, M.O., Rajab, M.S., Migwi, G.J. and Ndegwa, M. Blood pressure responses to an extract of Ajuga remota in experimental hypertensive rats. Planta Medica. 1993; 59: 573-574.

8. Kuria, K.A and Mariki, G.A. New cardiotonic agent from Ajuga remota Benth (Labiatae). East Afr. Med. J. 1984; 61:533-538.

9. Perez-Alonso, M.J., Velasco-Negueruela A., Duru, M.E, Harmandar, M. and Estedan J.L. Compositions of the essential Ocimum basilicum var glabratium and Rosamarinus officinalis from Turkey and their insecticide and insect repellent properties. J. Essential oil Res. 1995; 7:73-75.

10. Gupta, S.C. Variation in herbage yield, oil yield and major components of various Ocimum species varities (chemotypes) harvested at different stages of maturity. J. Essential oil Res. 1996; 8:275-279.

11. Desta, B. Ethiopian traditional herbal drug part II: Anti microbial activity of 63 medicinal plants. J. Ethnopharmacology. 1993; 39:129-139.

12. Koster, R., Anderson, M. and DeBeer, E.J. Acetic acid for analgesic screening. Fed. Proc. 1959; 18:412. 
13. Vaz, Z.R., Mata, L.V. and Calixto, J.B. Analgesic effect of herbal medicine Catuma in thermal and chemical models of nociception in mice. Phytotherapy Research. 1997; 11: 101-106.

14. Pasternak, G.W. Pharmacological mechanisms of opioid analgesics. Clin. Neuropharmacol. 1993; 16:1-18.

15. Dewey, W.J., Brase, D. and Welch, S.P. Pain control with opioid analgesics. In: Brody, T.M., Larner, J., Minnemann, K. P., Neu, H.C. (eds.): Human Pharmacology. 2nd edn. Mosby, St. Louis, 1994; 373-388

16. Trentin, A.P., Santos, A.R.S., Miguel, O.G., Pizzolatti, M.G.,
Yanes, R.A. and Calixto, J.B. Mechanisms involved in the antinociceptive effect in mice of the hydroalcoholic extract of Siphocampylus verticillatus. J. Pharm. Pharmacol. 1997; 49:567-572.

17. Brooks, P.M. and Day, R.O. Nonsteroidal anti-inflammatory drugs-differences and similarities. New. Engl. J. Med. 1991; 324:1716-1725.

18. Conner, J., Makonnen, E. and Rostom, A. Comparison of Analgesic Effects of Khat (Catha edulis Forsk) Extract, DAmphetamine and Ibuprofen in Mice. J. Pharm. Pharmacol. 2000; 52:107- 110 . 